Available for free online at https://ojs.hh.se/

$\mathfrak{J I S T B}$

Journal of Intelligence Studies in Business 3 (2013) 29-36

\title{
Intelligence in the Oil Patch: Knowledge Management and Competitive Intelligence Insights
}

\author{
Helen N. Rothberg ${ }^{1}$ and G. Scott Erickson ${ }^{2}$ \\ ${ }^{1}$ Marist College, Poughkeepsie, USA \\ ${ }^{2}$ Ithaca College, Ithaca, USA \\ Email: hnrothberg@aol.com, gerickson@ithaca.edu
}

Received October 10, accepted 25 December 2013

\begin{abstract}
The fields of knowledge management and competitive intelligence have been joined in the literature for over a decade, as scholars recognized the emphasis in each field on developing knowledge, albeit of different types. While knowledge management is often limited to the human, structural, and relational capital of the firm, competitive intelligence is more outward looking, building a broadly sourced knowledge base concerning competitors. In fact, practitioners are one step ahead of academia in this application as many organizations have a connection between their knowledge management and competitive intelligence functions. In extensive depth interviews to ascertain the state of intelligence work of all types in contemporary industry, we found such an inclination to be prominent in a number of specific industries. One of these was oil and gas. While exploration, recovery, refining, transportation, and retail are all separate aspects of this broad field, it is collectively of interest, in large part because of this extensive scope. In this paper, we compare and contrast knowledge management and competitive intelligence practice in oil-based industries. In doing so, we draw upon an extensive database including financial returns of thousands of companies in a broad range of industries over a five-year period. Looking specifically at industries related to oil and gas, we review data concerning the level and importance of knowledge assets in each industry. Included in the database is additional information on competitive intelligence activity in each industry. We add these figures to the analysis, allowing us to assess the relative competitive intelligence threat levels. Finally, we discuss the results from the depth interviews we conducted with practitioners in these industries, sharing their perspective on the nature of knowledge management, competitive intelligence, and the interplay between them in this complex industry.
\end{abstract}

KEYWORDS: Knowledge Management, Competitive Intelligence, Strategy, Tobin's q 


\section{Introduction}

Knowledge management (KM), intellectual capital, and competitive intelligence (CI) are all fields that grew up together over the past twenty-five years. A full review of all three disciplines in a short paper is almost impossible, so this literature summary will focus on some major concepts in KM and CI, similarities and differences, and how the fields interact.

$\mathrm{KM}$ and its related field, intellectual capital, evolved out of an interest in determining how and why firms are more competitive in the marketplace. As an extension to the resource-based theory of the firm (Wernerfelt 1984), scholars suggested that one unique, sustainable resource of the firm might be knowledge (Teece 1998; Grant 1996) and, indeed, this might be the only unique source of competitive advantage in the modern economy. Interest grew in what an organization's people might know and how that could be assessed, managed, and employed to best effect.

Intellectual capital theory and practice made up one side of this effort, specifically directed at defining and measuring the knowledge assets of the organization. These assets went beyond traditional intellectual property (patents, copyrights, etc.), including less well-defined, softer knowledge. Firms like Skandia (Edvinsson \& Malone 1997), the general business press (Stewart 1997), and scholars (Bontis 1999) all worked at developing definitions and metrics. These and related efforts resulted in the familiar categories and concepts of human capital, structural capital, and relational capital we know today.

While intellectual capital is chiefly concerned with the stock of knowledge assets, knowledge management has more to do with effectively managing and growing them (Zack 1999; Grant 1996). KM typically focuses on the nature of knowledge assets, organizational differences, and systems to best handle these differences while gaining participation from individuals throughout the firm. Regarding knowledge, the distinction between tacit and explicit knowledge (Polanyi 1967 ) is a critical one, particularly in terms of how to best develop those knowledge assets (Nonaka \& Takeuchi 1996). Depending on the extent of tacitness or explicitness, different approaches and techniques have been developed to aid person-toperson sharing or use of more digital approaches (Choi \& Lee 2003; Schulz \& Jobe 2001; Boisot 1995). Additional knowledge characteristics that may matter include complexity and specificity/stickiness (McEvily \& Chakravarthy 2002; Zander \& Kogut 1995; Kogut \& Zander 1992).

Organizational variables include aspects such as the absorptive capacity (Cohen \& Levinthal 1990) and the social capital (Nahapiet \& Ghoshal 1998) of an individual firm. Depending on the circumstances of a given organization, particular approaches to $\mathrm{KM}$ can be chosen, including communities of practice, mentoring, and knowledge markets (Brown \& Duguid 1991; Matson, Patiath \& Shavers 2003; Thomas, Kellogg \& Erickson 2001). Each also poses its own issues with workability, including how variables such as motivation and trust can influence participation. It's really a matter of choosing the right approach for the circumstances of the firm and can be a complex decision.

Competitive intelligence practice and study also grew during the past quarter century. The legal and ethical side of economic espionage, CI is the practice of collecting data and information about a competitor and/or its activities, processing and analyzing it for competitive insights, and acting on the results. As is the case with KM, CI also developed around practice (Gilad \& Herring 1996; Fuld 1994) as it was being noticed by the academic community (Prescott \& Miller 2001).

Scholarship on CI, much like KM, has focused on sources of information/knowledge (McGonagle \& Vella 2002) and techniques for using it (Fleisher \& Bensoussan 2002). The nature of the knowledge and organizational characteristics have been less of a concern but one could certainly see the field moving in that direction for future research. Of more interest to researchers are characteristics of CI teams or operations. Maturity appears to matter, with CI groups expanding their human intelligence networks and adding to their own analytical capabilities (Wright, Picton \& Callow 2002; Raouch \& Santi 2001).

One place where CI has already arrived is in deeper analysis of knowledge assets. Looking for 
actionable intelligence, CI teams are charged with understanding a competitor, its current strategies, and possible future strategies and actions (Gilad 2003; Bernhardt 1993). KM is likely headed in this direction, especially as the advent of big data and business intelligence work widens the view of valuable intangibles to include analyzable data and information. Even so, KM has yet to reach the same analytical level as CI.

So KM and CI have a number of similarities in terms of the identification and gathering of valuable intangible assets and the use of specific tools and techniques to manage them (Rothberg \& Erickson 2005; 2002). One other important interaction is in the likely increased CI vulnerability that comes from expanded KM efforts. One of the key aims of KM is to make more of a firm's knowledge stock available for use by many more employees. The result is more access points inside and outside the core company for competitors' CI operations, with access to a greater proportion of the firm's knowledge or information, in hard-to-monitor digital form. Greater dispersal of valuable proprietary assets can make them more at risk (Liebeskind 1996). As a consequence, there is a balance to be struck between development of knowledge and its protection, a balance that has only recently begun receiving scholarly attention (Liebowitz 2006; Rothberg \& Erickson 2005)

This paper reports on a study to examine more closely the relationship and interplay between KM and $\mathrm{CI}$ in practice. Looking at both objective results from a substantial database of financial returns and competitive intelligence activity and more subjective responses from practitioner interviews, we can more deeply study how KM and $\mathrm{CI}$ are managed in these closely related industries.

\section{Methodology and Results}

In looking to analyze knowledge development and protection across a number of firms and industries, one needs a tool capable of a certain amount of scope. Past work (Erickson \& Rothberg 2012; Rothberg \& Erickson 2005) has established that differences exist on the national, industry, and firm level that impact knowledge, so using industry and firm as the level of analysis, paired with an appropriate metric, can yield the kind of information we're seeking. Indeed, by following the Strategic Protection Factor framework, we can organize industries (and firms) by whether KM is important or not to industry success and whether CI is prevalent or not.

Measuring the knowledge development in a firm can be done in any number of ways (Sveiby 2010). Micro approaches tend to add up knowledge asset components in the firm to get a sense of the total intellectual capital. Given the difficulties in accessing such data, however, these approaches are usually limited to analysis of a single firm or a small group of related firms. This is how they have been used in practice (Lev \& Radhakrishnan 2003; Marr \& Schiuma 2001).

By taking a more macro approach and using more available financial data, many more firms can be analyzed at one time, allowing comparisons across industries (Tan, Plowman \& Hancock 2007; Firer \& Williams 2003). Such metrics are more appropriate in this case. In particular, we apply a variation on Tobin's q (Tobin \& Brainard 1977) that has been used previously in such applications (Erickson \& Rothberg 2012; 2009).

Tobin's q assesses the level of intangible assets of the firm, largely overlapping with the concept of the intellectual capital. The original value proposed by Tobin was market capitalization versus replacement value of assets. Replacement value of assets can be difficult to obtain, however, so a common variation is market cap to book value. For our purposes, we use market cap to asset valuethe difference being that book value subtracts out liabilities giving debt levels an impact on the measure (this makes a difference for industries like financial services with huge levels of borrowed capital). We just want to know the productivity of the firm given a certain tangible asset level, borrowed or owned, so we tend to prefer the market cap to assets approach. But both are included here for context. We also employ the metric as a ratio, eliminating firm size as a potential source of bias.

Financial data were obtained from the I/B/E/S service, including all firms trading on North American exchanges with at least $\$ 1$ billion in annual revenue. Data from 2005-2009 were included with over 7000 observations from over 2000 firms. The overall average for the market cap to asset ratio for the database was 1.02 . The overall average for the alternate market cap to book value metric was 2.68. Firms were grouped by industry (according to Standard Industrial Classification 
number) and industries with at least twenty observations were included in the analysis. For this paper, we looked at industries involved in oil and gas exploration, drilling, refining, and transmission/delivery.

Competitive intelligence metrics were taken from a benchmarking database constructed by Fuld \& Company, a major CI consultancy. These data were collected over a similar five-year period (20052009) and include over 1,000 worldwide respondents. We used a specific question on the maturity/professionalism of the CI function in the respondent's organization as our indicator. CI professionals included in the results rated their group's proficiency along a four-point scale, with 4 designating a highly developed capability and 1 suggesting a more ad hoc function. Again, we could group these by industry, using the same SIC codes and including specific organizations in the same place/industry in the data set. Depth interviews were conducted with practitioner contacts, participants solicited from training programs conducted by the authors, and other outreach efforts. No particular targeting by industry was done, participants were selected who participate in $\mathrm{KM}$ or CI (often both) at a senior level and with some substantive experience in at least one of the fields. Semi-structured interviews were conducted focusing on KM practice in their organization, CI practice, and any relationship between the two. Significant probing was done to provide additional depth.

Results are presented in Table 1. These include both Tobin's q metrics to assess the level of knowledge development required to compete in the industry (Cap/Assets, Cap/Book), our KM measures. Competitive intelligence activity is shown by the number of firms at each level of proficiency. A single firm at level 2 was the midpoint for the overall database, below that suggested low CI activity while multiple firms at 2 or at least one firm reporting 3 or above shows high CI activity. We also included the SPF (strategic protection factor) from Rothberg \& Erickson (2005) illustrating the competitive conditions facing each firm in terms of the combination of $\mathrm{KM}$ and CI results. We'll talk more about these shortly.

\begin{tabular}{|c|c|c|c|c|}
\hline Cap/Book & Cap/Assets & Cap/Book & $\begin{array}{l}\text { Competitive } \\
\text { Intelligence } \\
\text { (\#firms,\# } \\
\text { respondents) }\end{array}$ & $\begin{array}{l}\text { SPF } \\
\text { Category }\end{array}$ \\
\hline $\begin{array}{l}1311 \text { Crude Petroleum and } \\
\text { Natural Gas Exploration }\end{array}$ & 0.85 & 1.85 & $\begin{array}{l}4(0) \\
3(0) \\
2(4) \\
1(0)\end{array}$ & $\begin{array}{l}\text { SPF } 30 \\
\text { Low KM } \\
\text { High CI }\end{array}$ \\
\hline 1381 Drilling Oil/Gas Wells & 1.37 & 2.25 & $\begin{array}{l}4(1,6) \\
3(0) \\
2(0) \\
1(0)\end{array}$ & $\begin{array}{l}\text { SPF 45 } \\
\text { High KM } \\
\text { High CI }\end{array}$ \\
\hline 291 Petroleum Refining & 1.93 & 2.42 & $\begin{array}{l}4(0) \\
3(1) \\
2(1,2) \\
1(0)\end{array}$ & $\begin{array}{l}\text { SPF } 45 \\
\text { High KM } \\
\text { High CI }\end{array}$ \\
\hline 4922 Natural Gas Transmission & 0.58 & 1.82 & $\begin{array}{l}4(0) \\
3(0) \\
2(1) \\
1(0)\end{array}$ & $\begin{array}{l}\text { SPF } 5 \\
\text { Low KM } \\
\text { Low CI }\end{array}$ \\
\hline $\begin{array}{l}4923 \text { Natural Gas Transmission } \\
\text { \& Distribution }\end{array}$ & 0.80 & 2.25 & $\begin{array}{l}4(0) \\
3(0) \\
2(0) \\
1(0)\end{array}$ & $\begin{array}{l}\text { SPF } 5 \\
\text { Low KM } \\
\text { Low CI }\end{array}$ \\
\hline 4924 Natural Gas Distribution & 0.58 & 1.92 & $\begin{array}{l}4(0) \\
3(0) \\
2(0) \\
1(0)\end{array}$ & $\begin{array}{l}\text { SPF } 5 \\
\text { Low KM } \\
\text { Low CI }\end{array}$ \\
\hline
\end{tabular}

Table 1: Oil \& Gas Industries, Knowledge Management and Competitive Intelligence Status 


\section{Discussion}

There are a number of interesting things in the data, especially when paired with some of the insights from the interviews. But, as a first pass, let's focus on the nature of the data. The cap/asset ratio shows a range of knowledge development in the industries, some well above the overall average (drilling and refining), some below (exploration, transmission/distribution). Cap/book has a similar range of results but all the numbers are below the average of the full database. So this is an application where the choice of KM metric does matter and there is obviously something in the data leading to the differing results-probably the drilling and refining industries have substantially higher levels of debt, especially when compared to the transmission/distribution industries. As debt is not an important part of what we are trying to analyze, we believe the cap/asset result is the more reliable and preferred option.

The CI metric shows the number of firms and individuals within the firms reporting on their level of proficiency. Exploration, drilling, and refining all have higher than average levels of CI activity. In exploration, multiple firms (four) are all operating at a fairly organized level. Drilling only shows a single firm reporting a CI operation but it is at the highest level and included six team members independently responding to the benchmarking study, something very unusual in the dataset. Even if only a single firm, when you have someone in the industry operating at that level, it has major implications for the vulnerability of information and knowledge for everybody (as well as for the need for protection and counterintelligence). In refining, there are again multiple firms active in $\mathrm{CI}$, at the second and third levels, and one of those firms again has more than one respondent. Once more, this is in the upper half of CI activity for the full database. Such metrics, on their face, may not seem to illustrate substantial CI operations, but the people reporting in the survey are competitive intelligence professionals, generally managers of the group. So a single responder can be indicative of a much bigger operation, particularly when reporting above the lowest level of proficiency.

The three transmission/distribution industries show less activity. Only one individual reports an active operation in the three industries, and that is at the next to lowest proficiency level. Taken individually, all three industries are below the overall average for $\mathrm{CI}$ activity.

In terms of the Strategic Protection Factors represented here, the main point is that there are different industry conditions. In some industries, there is clear evidence of substantial development of intangibles or knowledge assets. Firms would probably need to aggressively grow their knowledge in such industries in order to keep up with competitors. In other industries, there is no indication of significant knowledge development and so no such mandate for investment in knowledge by member firms. Similarly, there are industries with heavy CI activity, industries with no $\mathrm{CI}$ activity, and a range of other results in between. What the SPF categorization does is indicate these conditions-where KM investment is important (or not) and where CI activity and/or protection is needed (or not). Such evidence leads to a logical conclusion that $\mathrm{KM}$ decisions may be more strategic than we often think (many KM scholars would recommend ever more investment into development) and that a better understanding of these types of conditions could lead to better spending decisions on both $\mathrm{KM}$ systems and $\mathrm{CI}$ offense and defense.

Depth interviews included conversations with four practicing managers working for oil and gas companies, chiefly in competitive intelligence. As might be expected, size of CI operations varied dramatically across such a small sample, from virtual teams formed for specific purposes to core groups of 30-40 to loose networks of up to 100 contributors. Budgets also varied dramatically, when individuals were willing to report them, from a couple hundred thousand dollars to $\$ 75$ million at one large integrated multinational. Key commonalities across the interviews included the distributed nature of many of the operations, being both task specific (information on joint ventures, mergers and acquisitions, market conditions, market entry, competitor strategies) or group specific (country, function, etc.). At the same time, there was a recognition that CI functions tend to become more centralized as they matured and senior management become more convinced of their value.

All of the respondents noted the often close relationship between $\mathrm{CI}$ and $\mathrm{KM}$, even if all efforts 
to integrate the two functions weren't successful. Both functions, often managed though the same office, seek to gather information and knowledge from throughout the firm and its larger network. Respondents noted a desire to incorporate the KM network into CI information-gathering and also using techniques such as communities of practice to good effect in both areas. There were comments about protecting knowledge, noting that these industries tend to be leaky. As a result, although knowledge might be gathered from throughout the firm and its extended network, it was not necessarily shared back out through the whole structure. Key knowledge was kept internal.

What can we conclude from the data and the interviews about these industries and their wider implications? Knowledge has different levels of importance at various points along the value chain, both in the firm and across the industry-wide chain. Firms that have a mandate to aggressively develop knowledge will often have key knowledge present in several places along the value chain, not just in a single spot (e.g. operations). That is seen clearly in this example. The industry value chain includes exploration through drilling, refining, and eventually transmission/delivery. One could include retail as well, though separating out gas stations in the data is difficult. Across this chain, the really valuable knowledge, at least from a knowledge development perspective, is in drilling and refining. This was reiterated in the interviews where those were the functions often mentioned by the respondents as being the key areas of attention for their offices. Not all knowledge is equally valuable or manageable, and this is true across industries and even across an individual firm.

Firms integrated across several distinct functions or industries, as a number of the major oil and gas majors are, should expect to face different conditions in these different arenas. Again, the value of the knowledge may differ. The range of competitive intelligence operations and activities may differ. The interplay between KM and CI may differ. Once more, there is strong evidence that a strategic approach is best, examining the knowledge development and protection conditions as they apply in each setting.

Part of that task would be understanding the type of knowledge involved. In some parts of the oil industry, the valuable knowledge is more tacit, potentially more valuable but also harder to manage effectively. Tacit knowledge is also harder for competitors to take by standard CI techniques. Similarly, if knowledge is more sticky or specific, it can have implications for sharing or competitive infiltration as could the complexity of the knowledge. The maturity of the industry comes into play and how much new, proprietary knowledge is being developed that is not easily available to everyone in the field. So drilling or refining, where tacit know-how can be extremely important but also quite personal, complex, and perhaps sticky poses a very different knowledge development/protection scenario than does something like transmission, where much knowledge is explicit, well-known throughout the industry, and complex but manageable using readily available logistics programs. The bottom line is, again, conditions differ, and strategists would be well-advised to understand the full conditions surrounding their knowledge development and knowledge protection decisions.

\section{Conclusions}

This paper has looked at knowledge practices in various oil and gas industries, specifically addressing the question of whether decision-makers should take more strategic decisions regarding knowledge development and protection. While the natural inclination of most of us working in the fields of $\mathrm{KM}$ and $\mathrm{CI}$ is that more is always better, both theory and practice suggest that sometimes a more measured approach may be better.

Knowledge has different levels of value in different industries included under the oil and gas designation. Development is critical in order to compete in industries such as drilling and refining while it may be less a priority in areas like exploration and transmission/distribution. Similarly, competitive intelligence can be a major threat, or not. CI activity levels are high in exploration, drilling, and refining but almost nonexistent in transmission/distribution. These industries also demonstrate an increasing integration in the $\mathrm{KM}$ and $\mathrm{CI}$ operations, according to respondent reports.

As a result, what we see in these industries helps to make the case for the more strategic approach to knowledge development and protection. Evaluating circumstances can help in determining 
when making larger investments in KM will pay off. Similarly, such strategic planning can better focus investments in CI offense and defense. Taking such a wider view can help increase the odds that KM and CI initiatives will actually pay off, providing greater opportunities for the disciplines to make a true contribution to modern business success.

\section{Acknowledgement}

The authors gratefully acknowledge the generosity of Fuld \& Company in providing some of the data used in this study.

\section{References}

Bernhardt, D. (1993) Perfectly Legal Competitive Intelligence-How to Get It, Use It and Profit From It, Pitman Publishing, London.

Boisot, M. (1995) "Is Your Firm a Creative Destroyer? Competitive Learning and Knowledge Flows in the Technological Strategies of Firms", Research Policy. 24, 489506.

Bontis, N. (1999) "Managing Organizational Knowledge by Diagnosing Intellectual Capital: Framing and Advancing the State of the Field", International Journal of Technology Management, 18(5-8), 433-462.

Brown, J.S. \& Duguid, P. (1991) "Organizational Learning and Communities-of-Practice: Toward a Unified View of Working, Learning, and Innovation", Organizational Science, 2(1), 4057.

Choi, B. \& Lee, H. (2003) "An Empirical Investigation of KM Styles and Their Effect on Corporate Performance". Information \& Management. 40, 403-417.

Cohen, W.M. \& Levinthal, D.A. (1990) "Absorptive Capacity: A New Perspective on Learning and Innovation", Administrative Science Quarterly, 35(1), 128-152.

Edvinsson, L. \& Malone, M. (1997) Intellectual Capital, Harper Business, New York.

Erickson, G.S. \& Rothberg, H.N. (2012) Intelligence in Action: Strategically Managing Knowledge Assets, Palgrave Macmillan, London.

Erickson, G.S. \& Rothberg, H.N. (2009) "Intellectual Capital in Business-to-Business Markets", Industrial Marketing Management, $38,159-165$.
Firer, S. \& Williams, S.M. (2003) "Intellectual Capital and Traditional Measures of Corporate Performance", Journal of Intellectual Capital, 4(3), 348-360.

Fleisher, C.S. \& Bensoussan, B. (2002) Strategic and Competitive Analysis: Methods and Techniques for Analysing Business Competition, Prentice Hall, Upper Saddle River, NJ.

Fuld, L.M. (1994) The New Competitor Intelligence: The Complete Resource for Finding Analyzing, and Using Information About Your Competitors, John Wiley, New York.

Gilad, B. (2003) Early Warning: Using Competitive Intelligence to Anticipate Market Shifts, Control Risk, and Create Powerful Strategies, AMACOM, New York.

Gilad, B. \& Herring, J., eds. (1996) The Art and Science of Business Intelligence, JAI Press, Greenwich, CT.

Grant, R.M. (1996) "Toward a Knowledge-Based Theory of the Firm", Strategic Management Journal, 17(Winter), 109-122.

Kogut, B. \& Zander, U. (1992) "Knowledge of the Firm, Combinative Capabilities, and the Replication of Technology", Organization Science. 3(3), 383-397.

Lev, B. \& Radhakrishnan, S. (2003) "The Measurement of Firm-Specific Organizational Capital", NBER Working Paper \#9581.

Liebeskind, J.P. (1996) "Knowledge Strategy and the Theory of the Firm", Strategic Management Journal, 17(Winter), 93-107.

Liebowitz, J. (2006). Strategic Intelligence: Business Intelligence, Competitive Intelligence, and Knowledge Management, Auerbach Publications, Boca Raton, FL.

Marr, B. \& Schiuma, G. (2001) "Measuring and Managing Intellectual Capital and Knowledge Assets in New Economy Organisations", in Bourne, M., ed., Handbook of Performance Measurement, Gee, London.

Matson, E, Patiath, P. \& Shavers, T. (2003) "Stimulating Knowledge Sharing: Strengthening Your Organizations' Internal Knowledge Market", Organizational Dynamics, 32(3), 275-285.

McEvily, S. \& Chakravarthy, B. (2002) "The Persistence of Knowledge-Based Advantage: An Empirical Test for Product Performance and Technological Knowledge", Strategic Management Journal, 23(4), 285-305.

Nahapiet, J. \& Ghoshal, S. (1998) "Social Capital, Intellectual Capital, and the Organizational 
Advantage", Academy of Management Review, 23(2), 242-266.

McGonagle, J. \& Vella, C. (2002). Bottom Line Competitive Intelligence, Quorum Books, Inc., Westport, CT.

Nonaka, I. \& Takeuchi, H. (1995) The KnowledgeCreating Company: How Japanese Companies Create the Dynamics of Innovation, Oxford University Press, New York.

Polanyi, M. (1967) The Tacit Dimension, Doubleday, New York.

Prescott, J.E. \& Miller, S.H. (2001) Proven Strategies in Competitive Intelligence: Lessons from the Trenches. New York: John Wiley and Sons.

Raouch, D. \& Santi, P. (2001) "Competitive Intelligence Adds Value: Five Intelligence Attitudes. European Management Journal, 19(5), 552-559.

Rothberg, H.N. \& Erickson, G.S. (2005) From Knowledge to Intelligence: Creating Competitive Advantage in the Next Economy, Elsevier Butterworth-Heinemann, Woburn, MA.

Rothberg, H.N. \& Erickson, G.S. (2002) "Competitive Capital: A Fourth Pillar of Intellectual Capital?", in Bontis, N., ed. World Congress on Intellectual Capital Readings, Elsevier Butterworth-Heinemann, Woburn, MA.

Schulz, M. \& Jobe, L.A. (2001) "Codification and Tacitness as Knowledge Management Strategies: An Empirical Exploration”, Journal of High Technology Management Research, 12, 139-165.

Stewart, T.A. (1997) Intellectual Capital: The New Wealth of Organizations, Doubleday, New York.
Sveiby, K-E (2010) "Methods for Measuring Intangible Assets", http://www.sveiby.com/articles/IntangibleMeth ods.htm, accessed 4/4/2012.

Tan H.P., Plowman, D. \& Hancock, P. (2007) "Intellectual Capital and the Financial Returns of Companies". Journal of Intellectual Capital. 9(1), 76-95.

Teece, D.J. (1998) "Capturing Value from Knowledge Assets: The New Economy, Markets for Know-How, and Intangible Assets", California Management Review, 40(3), 55-79.

Thomas, J.C., Kellogg, W.A. \& Erickson, T. (2001) "The Knowledge Management Puzzle: Human and Social Factors in Knowledge Management”, IBM Systems Journal, 40(4), 863-884.

Tobin, J. \& Brainard, W. (1977) "Asset Markets and the Cost of Capital", in Nelson, R. \& Balassa, B., eds. Economic Progress, Private Values, and Public Policy: Essays in Honor of William Fellner, North Holland, Amsterdam.

Wernerfelt, B. (1984) "The Resource-based View of the Firm", Strategic Management Journal, 5(2), 171-180.

Wright,S., Picton, D. \& Callow, J. (2002) "Competitive Intelligence in UK Firms, A Typology", Marketing Intelligence and Planning, 20(6), 349-360.

Zack, M.H. (1999) "Developing a Knowledge Strategy" California Management Review. 41(3), 125-145.

Zander, U. \& Kogut, B. (1995) "Knowledge and the Speed of Transfer and Imitation of Organizational Capabilities: An Empirical Test", Organization Science, 6(1), 76-92. 